\title{
APPROPRIATIONS CONTROL AND THE ATOMIC ENERGY PROGRAM*
}

\author{
Morgan Thomas \\ University of Michigan
}

PPROPRIATIONS bills for the United States Atomic Energy Com-
mission usually bring forth strong protests from members of the Joint
Committee on Atomic Energy, predicting severe curtailment of the AEC program if the Appropriations Committees' bills are enacted as drafted. ${ }^{1}$ But the Joint Committee's proposed rectifying amendments are rarely accepted, and each Appropriations Committee in House and Senate usually is successful in having these bills passed in the form in which they come from committee. Without further investigation one could easily conclude that the Appropriations Committees are exerting a high degree of appropriations control over the Atomic Energy Commission in the process of appropriating funds. To discover whether this easy assumption is or is not true is the objective of this study.

By appropriations control is meant the influence Congress exerts through its "power of the purse": the exclusive power to appropriate funds for the functioning of the federal government. In exercising appropriations control the Congress works chiefly through its agents, the Appropriations Committee in the House of Representatives and its counterpart in the Senate. The degree of control which these two committees can exercise over administrative agencies is gauged chiefly in two ways. First, how much do these committees reduce the money total budgeted for an administrative agency? Under the federal government's system of lump-sum appropriations this is curtailment of the roughest kind. Second, what appropriation language limitations do the committees place on the use of personal services and other objects of expenditure and on the procedures and practices of an administrative agency? This type of control is more specific and is directed at an administrative facet of the program.

Appropriations control is also exercised by means of "suggestions" or "warnings" made in committee reports or in oral exchanges at the hearings. If these are not followed, legal and more stringent restrictions are likely to be inserted in the appropriations bill the next year, or a committee in-

\footnotetext{
* Data for this study were gathered in the course of group research supported by the Michigan-Memorial Phoenix Project at the University of Michigan. The Phoenix Project is devoted to research in the peacetime applications of atomic energy.

${ }^{1}$ For an analysis of the role of the Joint Committee on Atomic Energy in the atomic energy program, see Morgan Thomas, Atomic Energy and Congress (Ann Arbor: University of Michigan Press, 1956).
} 
vestigation is likely to arouse disapproval of agency actions by the general public or an influential group. But these informal power relationships between the Appropriations Committees and administrative agencies are in most cases too subtle for systematic study. And in this particular case, as will be seen, the AEC's high degree of independence renders appropriations control by these informal means decidedly ineffectual. Therefore this analysis of appropriations control over the atomic energy program will use as general gauges only the two definite controls through curtailment of total dollars appropriated and through administrative and procedural restrictions.

\section{Curtailment of Total Dollars Appropriated}

For the sake of simplicity it is possible to consolidate the three different forms of budget authorizations which Congress has enacted for the AEC (appropriations of new obligational authority, contract authorizations, and appropriations of cash to liquidate prior year contract authority), because the percentage of reductions made by the Congress in the AEC total budget authorizations is almost the same as that made in new obligational authority ${ }^{2}$ and as that made in cash appropriations. ${ }^{3}$ Furthermore, no obligational authority has ever been lost by the Atomic Energy Commission, because Congress at the end of each fiscal year has always reappropriated unobligated appropriations and reauthorized unobligated contract authorizations. ${ }^{4}$ Hence, the total of the obligational authority granted to the Commission since the program started equals the total amount available for expenditure.

As with all requests for appropriations, those of the Atomic Energy Commission are considered first by the House of Representatives through its Committee on Appropriations. ${ }^{5}$ These AEC estimates have been as printed in the President's budget document, except for five occasions when they were reduced before the House had a chance to act on the initial

${ }^{2}$ New obligational authority can be derived by subtracting the cash to liquidate prior year contract authority from the total budget authorizations.

${ }^{3}$ Cash appropriations can be derived by deducting contract authorizations from the total budget authorizations.

4 The only case of rescission of contract authority was a cancellation of $\$ 635,623$ made at the AEC's request in 1952 when the AEC converted entirely to a cash appropriation basis.

The actual hearings and the preparation of the appropriation bill take place in a subcommittee, which for the AEC up to the 84 th Congress was that on Independent Offices. In the period prior to 1944 all funds for atomic energy were hidden under other appropriations, but as the magnitude of the operation increased the administration found it necessary to take Congressional leaders into confidence in order to establish separate appropriations. Thus from 1944 to 1946 , the period immediately before the organization of the AEC, appropriations were piloted through Congress by the leadership without any public discussion. See Henry L. Stimson and McGeorge Bundy, On Active Service in Peace and War (New York: Harper \& Bros., 1947), p. 614 . 
budget requests. In order to include these five cases of reductions, the AEC estimates are referred to as revised estimates in the accompanying tables. ${ }^{6}$

The average reduction from these revised estimates by the House of Representatives was about 22 per cent. In this average is a 50 per cent reduction in the supplemental appropriation bill for fiscal year 1953 for the purpose of enforcing fuller construction planning rather than holding back the program by that amount. When this outstanding but misleading reduction is eliminated, the average reductions made by the House are about 12 per cent below the revised estimates (see Table I).

TABLE I

House Action on AEC Appropriations Requests*

(in millions of dollars)

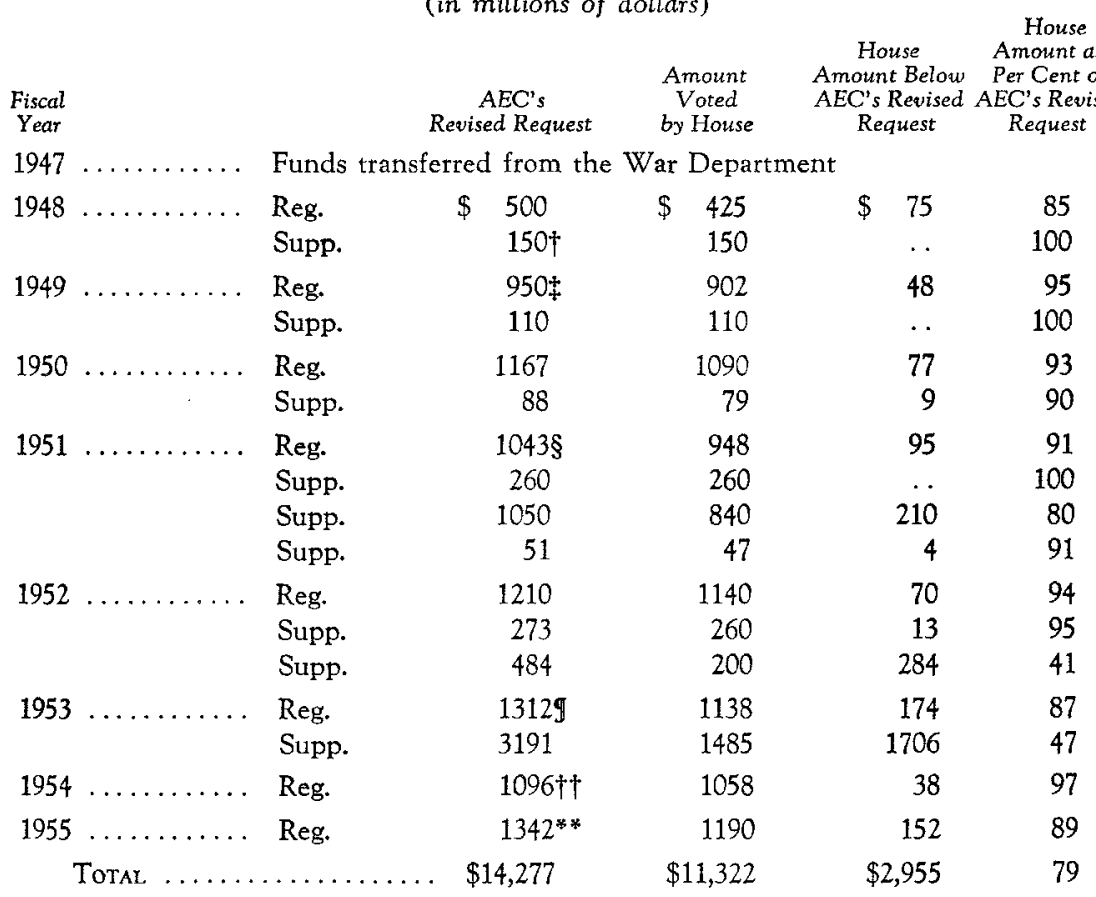

* Includes both cash and contract authority.

$\uparrow$ AEC estimates reduced from $\$ 200$ million prior to House action.

¥ AEC estimates reduced from $\$ 1,025$ million prior to House action.

$\$$ AEC estimates reduced from $\$ 1,060$ million prior to House action.

$\$ \$ 635,623$ of contract authority was rescinded this year at AEC's request.

†† AEC estimates reduced from $\$ 1,593$ million prior to House action.

** AEC estimates reduced from $\$ 1,366$ million prior to House action.

\footnotetext{
${ }^{6}$ The total effect of these revisions has been a reduction of $\$ 663$ million, of which $\$ 497$ million came in the Eisenhower administration's first budget for fiscal year 1954. Report to Accompany H. R. 5690, Independent Offices Appropriations Bill, 1954, 83d Cong., 1st Sess., H. R. Rep. No. 550, pt. 1, p. 13, and pt. 2, p. 1 (June 11, 1953).
} 
TABLE II

Senate Action on AEC Appropriattons Requests* (in millions of dollars)

\begin{tabular}{|c|c|c|c|c|c|c|}
\hline $\begin{array}{l}\text { Fiscal } \\
\text { Year }\end{array}$ & & $\begin{array}{l}\text { AEC's } \\
\text { Revised } \\
\text { Request }\end{array}$ & $\begin{array}{c}\text { Amount } \\
\text { Voted } \\
\text { by Senate }\end{array}$ & $\begin{array}{c}\text { Senate Amount } \\
\text { Above } \\
\text { That Voted } \\
\text { by House }\end{array}$ & $\begin{array}{c}\text { Per Cent } \\
\text { Increase } \\
\text { Over House } \\
\text { Amount }\end{array}$ & $\begin{array}{c}\text { Senate } \\
\text { Amount } \\
\text { as Per Cen } \\
\text { of AEC's } \\
\text { Revised } \\
\text { Request }\end{array}$ \\
\hline$\ldots \ldots$ & Funds & erred fron & War Des & rtment & & \\
\hline $1948 \ldots \ldots \ldots$ & $\begin{array}{l}\text { Reg. } \\
\text { Supp. }\end{array}$ & $\begin{array}{r}\$ 500 \\
150\end{array}$ & $\begin{array}{r}\$ 500 \\
150\end{array}$ & $\begin{array}{l}75 \\
\cdots\end{array}$ & $\begin{array}{l}18 \\
\ldots\end{array}$ & $\begin{array}{l}100 \\
100\end{array}$ \\
\hline $1949 \ldots \ldots$ & $\begin{array}{l}\text { Reg. } \\
\text { Supp. }\end{array}$ & $\begin{array}{l}950 \\
110\end{array}$ & $\begin{array}{l}922 \\
110\end{array}$ & $\begin{array}{l}20 \\
\ldots\end{array}$ & $\begin{array}{c}2 \\
\cdots\end{array}$ & $\begin{array}{r}97 \\
100\end{array}$ \\
\hline$\ldots \ldots \ldots$ & $\begin{array}{l}\text { Reg. } \\
\text { Supp. }\end{array}$ & $\begin{array}{r}1167 \\
88\end{array}$ & $\begin{array}{r}1090 \\
79\end{array}$ & $\begin{array}{l}\cdots \\
\ldots\end{array}$ & $\begin{array}{l}\cdots \\
\cdots\end{array}$ & $\begin{array}{l}93 \\
90\end{array}$ \\
\hline $1951 \ldots \ldots \ldots$ & $\begin{array}{l}\text { Reg. } \\
\text { Supp. } \\
\text { Supp. } \\
\text { Supp. }\end{array}$ & $\begin{array}{r}1043 \\
260 \\
1080 \dagger \\
64 \ddagger\end{array}$ & $\begin{array}{r}948 \\
260 \\
1080 \\
59\end{array}$ & $\begin{array}{r}\ldots \\
240 \\
12\end{array}$ & $\begin{array}{l}\cdots \\
\ddot{29} \\
26\end{array}$ & $\begin{array}{r}91 \\
100 \\
100 \\
92\end{array}$ \\
\hline $1952 \ldots \ldots \ldots$ & $\begin{array}{l}\text { Reg. } \\
\text { Supp. } \\
\text { Supp. }\end{array}$ & $\begin{array}{r}1210 \\
273 \\
484\end{array}$ & $\begin{array}{r}1169 \\
272 \\
200\end{array}$ & $\begin{array}{l}29 \\
12 \\
\ldots\end{array}$ & $\begin{array}{r}3 \\
5 \\
\ldots\end{array}$ & $\begin{array}{l}97 \\
99 \\
41\end{array}$ \\
\hline $1953 \ldots \ldots \ldots$ & $\begin{array}{l}\text { Reg. } \\
\text { Supp. }\end{array}$ & $\begin{array}{l}1312 \\
3191\end{array}$ & $\begin{array}{l}1138 \\
3660\end{array}$ & $2 \ddot{175}$ & $\ddot{146}$ & $\begin{array}{r}87 \\
115\end{array}$ \\
\hline 1954 & Reg. & 1096 & 1058 & $\cdots$ & $\ldots$ & 97 \\
\hline $1955 \ldots \ldots \ldots$ & Reg. & 1342 & 1233 & 43 & 4 & 92 \\
\hline Total & & $\$ 14,320$ & $\$ 13,928$ & $\$ 2,606$ & 22 & 97 \\
\hline
\end{tabular}

* Includes both cash and contract authority.

$\uparrow$ AEC estimates increased from $\$ 1050$ million prior to Senate action.

$\ddagger$ AEC estimates increased from $\$ 51$ million prior to Senate action.

The Senate Committee on Appropriations, considering agency budgets after House action is completed, generally makes partial restoration of House cuts. These increases can be represented as percentages above the House allowances. For the AEC, by excluding again the misleading 1953 situation in which the Senate raised the House allowance by 146 per cent, the average increase voted by the Senate (done only in eight out of seventeen appropriations bills) was somewhat over 4 per cent. ${ }^{7}$ More significantly, Senate action produced an average reduction of only 3 per cent from the AEC's revised estimates (see Table II).

\footnotetext{
${ }^{7}$ In two cases small increases in estimates totaling $\$ 43$ million were made by the AEC after the House action on the AEC budget but before the Senate Committee had made its report. In these two cases these additional amounts were added to make up the AEC's revised requests. Report to Accompany H. R. 9920, Supplemental Appropriations Bill, 1951, 81st Cong., 2d Sess., Sen. Rep., p. 2684 (December 20, 1950), and Report to Accompany H. R. 3842, Fourth Supplemental Appropriations Bill, 1951, 82d Cong., 1st Sess., Sen. Rep. No. 329, p. 2 (May 22, 1951).
} 
When the differences between the House and Senate were compromised (usually at an amount very near to an average between the two amounts), the average by which the actual appropriations fell below the AEC's revised estimates was 9 per cent (see Table III). But this percentage exaggerates the final net effect of appropriations control. Such distortion comes about for two reasons.

First, Congress often makes a record of reduction by cuts which are likely to be restored during the fiscal year. Thus on several occasions cuts voted by the Appropriations Committees have been accompanied by statements like the following:

In view of the assurance of AEC officials that funds already provided will meet all requirements until early next spring the Committee has effected a reduction of $\$ 284$, 200,000 in the supplemental request of $\$ 484,200,000$, leaving a total of $\$ 200,000,000$, which

TABLE III

Final Action on AEC APpropriations Requests * (in millions of dollars)

\begin{tabular}{|c|c|c|c|c|c|c|c|}
\hline \multirow{2}{*}{$\begin{array}{l}\text { Fiscal } \\
\text { Year } \\
1947\end{array}$} & & $\begin{array}{l}\text { AEC's } \\
\text { Revised } \\
\text { Request }\end{array}$ & $\begin{array}{l}\text { Actual } \\
\text { Approp. }\end{array}$ & $\begin{array}{c}\text { Final } \\
\text { Approp. } \\
\text { Over } \\
\text { Amt. Voted } \\
\text { by House }\end{array}$ & $\begin{array}{c}\text { Final } \\
\text { Approp. } \\
\text { Under } \\
\text { Amt. Voted } \\
\text { by Senate }\end{array}$ & $\begin{array}{l}\text { Final } \\
\text { Approp. } \\
\text { Under } \\
\text { Revised } \\
\text { Request }\end{array}$ & \multirow[t]{2}{*}{$\begin{array}{c}\text { Final } \\
\text { Approp. as } \\
\text { Per Cent of } \\
\text { Revised } \\
\text { Request }\end{array}$} \\
\hline & \multicolumn{6}{|c|}{ Funds transferred from War Department } & \\
\hline 1948 & $\begin{array}{l}\text { Reg. } \\
\text { Supp. }\end{array}$ & $\begin{array}{l}500 \\
150\end{array}$ & $\begin{array}{l}425 \\
150\end{array}$ & $\begin{array}{l}\ldots \\
\ldots\end{array}$ & $\begin{array}{l}75 \\
. .\end{array}$ & $\begin{array}{l}75 \\
\ldots\end{array}$ & $\begin{array}{r}85 \\
100\end{array}$ \\
\hline 1949 & $\begin{array}{l}\text { Reg. } \\
\text { Supp. }\end{array}$ & $\begin{array}{l}950 \\
110\end{array}$ & $\begin{array}{l}912 \\
110\end{array}$ & $\begin{array}{l}10 \\
\cdots\end{array}$ & $\begin{array}{l}10 \\
\cdots\end{array}$ & $\begin{array}{l}38 \\
\ldots\end{array}$ & $\begin{array}{r}96 \\
100\end{array}$ \\
\hline 1950 & $\begin{array}{l}\text { Reg. } \\
\text { Supp. }\end{array}$ & $\begin{array}{r}1167 \\
88\end{array}$ & $\begin{array}{r}1090 \\
79\end{array}$ & $\begin{array}{l}. \\
. .\end{array}$ & $\begin{array}{l}\cdots \\
\cdots\end{array}$ & $\begin{array}{r}77 \\
9\end{array}$ & $\begin{array}{l}93 \\
90\end{array}$ \\
\hline 1951 & $\begin{array}{l}\text { Reg. } \\
\text { Supp. } \\
\text { Supp. } \\
\text { Supp. }\end{array}$ & $\begin{array}{r}1043 \\
260 \\
1080 \\
64\end{array}$ & $\begin{array}{c}948 \\
260 \\
1065 \\
59\end{array}$ & $\begin{array}{c}. \\
225 \dagger \\
12 \ddagger\end{array}$ & $\begin{array}{l}. \\
\ddot{15}\end{array}$ & $\begin{array}{r}95 \\
. \\
15 \\
5\end{array}$ & $\begin{array}{r}91 \\
100 \\
99 \\
92\end{array}$ \\
\hline 1952 & $\begin{array}{l}\text { Reg. } \\
\text { Supp. } \\
\text { Supp. }\end{array}$ & $\begin{array}{r}1210 \\
273 \\
484\end{array}$ & $\begin{array}{r}1140 \\
266 \\
200\end{array}$ & $\begin{array}{c}. \\
6 \\
. .\end{array}$ & $\begin{array}{r}29 \\
6 \\
\ldots\end{array}$ & $\begin{array}{r}70 \\
7 \\
284\end{array}$ & $\begin{array}{l}94 \\
97 \\
41\end{array}$ \\
\hline 1953 & $\begin{array}{l}\text { Reg. } \\
\text { Supp. }\end{array}$ & $\begin{array}{l}1312 \\
3191\end{array}$ & $\begin{array}{l}1138 \\
2987\end{array}$ & 1502 & $\ddot{73}$ & $\begin{array}{l}174 \\
204\end{array}$ & $\begin{array}{l}87 \\
94\end{array}$ \\
\hline 1954 & Reg. & 1096 & 1058 & .. & . & 38 & 97 \\
\hline 1955 & Reg. & 1342 & 1210 & 20 & 23 & 132 & .90 \\
\hline Total & and & $\$ 14,320$ & $\$ 13,097$ & $\$ 1,775$ & $\$ 831$ & $\$ 1,223$ & 91 \\
\hline Total & only $\ldots$. & $\$ 12,671$ & $\$ 11,531$ & & & & 91 \\
\hline
\end{tabular}

* Includes both cash and contract authority.

$\dagger$ This difference includes an additional $\$ 30$ million AEC requested after House action.

$\$$ This difference includes an additional $\$ 13$ million AEC requested after House action. 
will be entirely sufficient to meet any emergency needs for additional funds which may arise prior to the time Congress has had a further opportunity to review the program. ...

If just this $\$ 284,200,000$ were deducted from AEC's total requests, the estimates received as appropriations would rise by 2 per cent (to 93 per cent).

Second, AEC estimates have been considerably less firm than those of most other government agencies. ${ }^{9}$ This fact has prompted Congress to make reductions in the hope of finding later that the AEC estimates were too high and of making the AEC subsequently budget more carefully. ${ }^{10}$ The following quotation from a report of the House Committee thus explained reductions which it had voted:

... the Commission admitted during the hearings that estimates could vary as much as 25 to $331 / 3 \%$. Under these circumstances the committee believes that the reduction can be made without hampering or slowing down this important program, and that additional funds can be provided where more accurate estimates are available and the need therefor demonstrated. ${ }^{11}$

In actuality, additional funds have been provided frequently during a single fiscal year. For example, from 1948 to 1953 the AEC had an average of two and one-half appropriations bills per fiscal year. Obviously chances for restorations of reductions have been good.

It is impossible to evaluate with any precision the effect of these two factors on the amount of reduction in AEC estimates made by Congress. Nevertheless, there is no doubt that they have worked to soften the effect of an already not-too-severe average reduction of 9 per cent in AEC's estimates. As has previously been pointed out, this percentage is well within

${ }^{8}$ Report to Accompany H. R. 5650, Second Supplemental Appropriations Bill, 1952, 82d Cong., 1st Sess., H. R. Rep. No. 1180, p. 13 (October 8, 1951). See also the subcommittee chairman's statement in the House, 93 Cong. Rec., 80th Cong., 1st Sess., p. 10043 (July 24, 1947).

- This is an understandable condition for budgets for huge construction programs carried on under conditions of such urgency and haste that budget estimates have been made as much as two or three years before plans and specifications are completed and sometimes even before sites have been selected.

${ }^{10}$ The impression should not be left that the AEC estimates have always been either too high or too low. While the attention of Congress and the public has been drawn to incidents in which costs greatly exceeded budget estimates, such as the Hanford overrun, there have been numerous other occasions on which actual costs have been

- well below budget estimates. On an over-all basis, estimates that were high and estimates that were low offset one another, as evidenced by General Electric's report on 57 major construction projects at Hanford, on all of which actual costs exceeded budget estimates by less than one per cent (Investigation into the United States Atomic Energy Project, Hearings before the Joint Committee on Atomic Energy, 81st Cong., 1st Sess., pt. 8, p. 356). Also the House Subcommittee went so far as to complain, in connection with its review of the 1955 estimates, that the AEC had in the past generally over-estimated its requirements for funds. The Subcommittee then used this alleged fact as its justification for eliminating contingency funds from the estimate. Report to Accompany H. R. 8583, Independent Offices Appropriations Bill, 1955, 83 d Cong., 2d Sess., H. R. Rep. No. 1428, p. 10 (March 26, 1954).

${ }^{11}$ Report to Accompany H. R. 9920, Second Supplemental Appropriations Bill, 1951, 81st Cong., 2d Sess., H. R. Rep. No. 3193, p. 15 (Dec. 15, 1950). 
the margin of error in most of the AEC's budget estimates. Hence it is concluded that Congress has not exercised great influence over the scope and tempo of the atomic energy program from the standpoint of actual total dollars appropriated.

\section{Administrative and Procedural Restrictions}

Formal limitations providing control over an administrative agency can be made by the Appropriations Committees in the form of various kinds of restrictions added to the language of an appropriation act. Such provisos, often added in bewildering profusion and complexity, all stem from the general intent to circumscribe the agency's freedom of action. Language limitations attached to the AEC's appropriations have been grouped into four general areas: personnel, travel, construction, and community management.

\section{Personnel}

Congressional Appropriations Committees are particularly concerned about the use of manpower in government, and they generally believe that administrators are prone to want more and more personnel in highly paid positions. They therefore employ various forms of personnel restrictions added to the language of appropriations acts. These will now be taken up in turn as they have been applied to the Atomic Energy Commission.

Salary Classifications. The original freedom granted to the AEC in its organic act to set up its own salary classifications was limited by a proviso which the House Appropriations Committee successfully added to the fiscal year 1948 Appropriations Act in 1947.12 For scientific and technical personnel the Committee was willing to leave the freedom of the Commission intact, but for managerial personnel, the Committee required the Commission to follow the Classification Act of 1923 in setting classification grades and salaries for its staff. In the Senate debate on this bill, three members of the Joint Committee on Atomic Energy attempted, but failed, to define "scientific and technical personnel" to include practically all managerial personnel of the AEC. In the following two fiscal years the AEC continued without avail to request the deletion of this proviso bringing its managerial personnel within the salary scale of the federal civil service.

The stringency of this limitation on maximum salaries was partially relieved shortly after the new Classification Act was passed in 1949. This Act provided for three new grades above the preceding maximum for all

\footnotetext{
${ }^{12}$ Pub. L. No. 269, 80th Cong., 1st Sess., 61 Stat. at L. 589, subsequently rephrased to incorporate the terminology of the "Classification Act of 1949" (Pub. L. No. 429, 81st Cong., 1st Sess., 63 Stat. at L. 959) in the "Independent Offices Appropriations Act of 1952," Pub. L. No. 137, 82d Cong., 1st Sess., 65 Stat. at L. 269. All appropriation acts from 1947 to 1955 inclusive have included this proviso.
} 
agencies covered by civil service regulations. The AEC was quick to secure from the General Accounting Office an informal interpretation that the 1949 Classification Act could be extended to the AEC, which allowed the $A E C$ to pay its managerial personnel at the higher salaries. Under this Act each federal agency was assigned a specific quota of these "supergrades" (as they were called), but the AEC was not so limited. ${ }^{13}$

Personnel Employees' Ratio. Another device employed by the Appropriations Committees has been that of fixing a ratio of the number of persons engaged in personnel work to the total employment in a federal agency. The Independent Offices Subcommittees have inserted this requirement into their annual appropriations bills since fiscal year 1950.14

Specific requests for exemption of the AEC from this limitation in connection with the bills for fiscal years 1950 and 1953 were not granted. However, the AEC has had a distinct advantage over other agencies in operating under this proviso. The AEC, having its personnel work merged with "organization and methods" work in one division, has been able to assign additional employees to personnel duties on less than half-time and thus not count them as personnel workers. In effect, the AEC has not been burdened by this conventional ratio.

Limitations on Personal Services. One method of requiring reductions in personnel took the form of a general formula known as the Jensen amendment. First proposed in 1951, it was actually included in most appropriations acts in fiscal years 1952 and $1953 .{ }^{15}$ It prohibited agencies from filling three out of four vacancies which occurred in their organization until a reduced level of employment (usually 90 per cent) had been reached. The Commission was subject to the Jensen amendment for two or three months, between the passage of its regular 1952 appropriation and the 1952 supplemental appropriation, in which it was exempted. While the AEC may have been slightly inconvenienced during this period, it escaped the major impact which this amendment had on nearly all other agencies of the government.

In recent years the Appropriations Committees have seen fit to apply to administrative agencies an appropriation limitation on the total dollars spent for personal services. Such limitations, not applied to the AEC until fiscal year 1952, have been included in each of the AEC's appropriations since that year. In all cases the amount established as a limitation was well below the amount included by the Commission for personal services in its budget estimate.

\footnotetext{
${ }^{13}$ Independent Offices Appropriations for 1953, Hearings before the subcommittee of the House Committee on Appropriations, 82d Cong., 2d Sess., p. 1123. Also see 63 Stat. at L. 959.

${ }^{14}$ Pub. L. No. 266, 81st Cong., 1st Sess., 63 Stat. at L. 634.

${ }^{15}$ Pub. L. No. 137, 82d Cong., 1st Sess., 65 Stat. at L. 292, sec. 605 (i).
} 
But the AEC has had available a significant loophole. Its system of operating through private contractors has permitted considerable flexibility in assigning functions to contractor personnel instead of government employees. For example, while the guards at Los Alamos laboratory are civil servants, those at most other AEC installations are employed by the contractors who operate them. Similarly, chauffeurs, telephone operators, maintenance and repair crews, and so forth, may be government employees at one installation and contractor employees at another. Unquestionably the opportunity for shifting functions from government to contractor personnel exists, ${ }^{16}$ but it is impossible to determine the degree to which this device has been employed by the AEC to evade limitations on its personnel imposed by Congress.

All in all, the AEC has not been subjected to as much appropriations control in regard to its employment of personnel as have most other civilian executive agencies.

\section{Travel}

An appropriation limitation on the total amount the AEC could obligate for travel appeared first in fiscal year 1949. ${ }^{17}$ Then it reappeared in the appropriations acts for the fiscal years 1954 and 1955. Many agencies have had this kind of restriction practically every year, and thus the AEC has been restricted in this way much less frequently than other agencies. Furthermore, the opportunity to shift some travel activities from the Commission to the contractors has been available here also.

\section{Construction}

In the area of construction procedures the Appropriations Committees have made their greatest effort in an attempt to require what they regard as economical methods. The AEC, believing that much time can be saved, has simultaneously carried on design, procurement, and construction activities for new plants and facilities. This is not in accordance with the usual commercial procedure, in which design precedes procurement and procurement precedes construction. For their part, the Appropriations Committees, and the House Committee in particular, have stressed the generally uneconomical nature of this unusual AEC procedure and the corresponding roughness of its budget estimates, often prepared before any detailed design work has been started or a site selected. Accordingly, the Committees successfully inserted in the 1950 appropriations a provision which would prevent the Commission from (1) starting any new construction project for which an estimate was not included in the budget, and (2) starting

\footnotetext{
${ }^{10}$ Independent Offices Appropriations Bill, 1950, Hearings before the subcommittee of the Committe on Appropriations, 81st Cong., 1st Sess., pp. 1106-1109.

${ }^{17}$ Pub. L. No. 862, 80th Cong., 2d Sess., 62 Stat. at L. 1197.
} 
any new construction project, the currently estimated cost of which exceeded the estimated cost included in the budget, unless the Director of the Bureau of the Budget specifically approved of the construction and a detailed explanation was submitted by that Director to the Appropriations Committees and the Joint Committee on Atomic Energy. ${ }^{18}$ This Act also provided that whenever the current estimate of the cost of a construction project exceeded by 15 per cent the estimate included in the budget for that project, the Commission was required to submit a detailed explanation to the Bureau and the three committees named before.

Three months later, probably as a result of the knowledge that the Soviet Union had an A-bomb, most of the stringency was taken out of these provisions by an amendment, sponsored by the Joint Committee on Atomic Energy, allowing the Commission to ignore the above provisions in undertaking the construction of "technical and construction facilities" if it certified to the Director of the Bureau of the Budget that immediate construction was necessary to the "national defense and security," and if the Director agreed. ${ }^{19}$ The principal effect of this change was to free the Commission from detailed justification of new construction required previously by the superseded provisos.

For 1953, the House Committee revised the construction rider to provide that the AEC might not start any construction project for which an estimate was not included in the budget or whose currently estimated cost exceeded by 35 per cent the amount included in the budget estimate. ${ }^{20}$ Despite the Commission's plea that the Budget Bureau escape clause be restored and that architect-engineer work be exempted along with projects amounting to less than $\$ 250,000$, the proviso was passed as originally conceived.

In the 1953 Supplemental Appropriations Bill, the House Committee made its supreme effort to require the Commission's compliance with its notion of businesslike procedures. The Committee cut by 53 per cent the funds requested by the Commission to finance the fiscal 1953 expansion program, and at the same time added to the restrictions one which provided that no part of the appropriation could be used for the construction of any project unless funds were available for the completion of such project. ${ }^{21}$ The intent here was to force the Commission to complete the

\footnotetext{
${ }^{18}$ The limitations contained in this proviso were not to apply to any construction project where the total estimated cost did not exceed $\$ 500,000$. See Pub. L. No. 266, 81st Cong., 1st Sess., 63 Stat. at L. 634.

${ }^{19}$ This bill, Sen. 2668 of the 81 st Cong., became Public Law No. 422, approved October 28, $1949 ; 63$ Stat. at L. 947.

${ }^{20}$ Pub. L. No. 445, 82d Cong., 2d Sess., 66 Stat. at L. 395.

${ }^{21}$ Report to Accompany H. R. 8370, Supplemental Appropriations Bill, 1953, 82d Cong., 2d Sess., H. R. Rep. No. 2316, p. 23 (June 26, 1952).
} 
design of a project (in order to ascertain its total cost) before beginning construction and to permit the Committee to look at these estimates before appropriating the balance of the funds required.

Although the latter objective was thwarted by the compromise finally worked out, which accepted the Senate's desire to appropriate the full amount requested for the expansion program, the former objective of forcing firmer estimates on all construction projects was accomplished. A special procedure for making these estimates and reporting them for consolidation in the office of the AEC's Director of Finance was instituted by the Commission to operate in keeping with the requirements of this proviso. ${ }^{22}$ The cumulative effect, then, of these construction provisos has been to induce more complete planning prior to construction in the Commission's expansion programs. ${ }^{23}$

\section{Community Management}

The House Appropriations Committee reports for fiscal years 1949 and 1950 recommended sizable reductions in Commission expenditures for town operations management fees. ${ }^{24}$ Evidently dissatisfied with the Commission's response to these recommendations, the Committee included in the fiscal year 1951 bill a dollar limitation on the fees which the Commission could pay to its community management contractors. Despite predictions by both Commissioners and Joint Committee members that dire results would follow, the House Committee succeeded in forcing through this proviso, which in effect cut in half the fees paid community management contractors at Oak Ridge. Afterward, the Commission was able to shift the contract to certain staff members of the previous contractor who formed a new company to take over the community management function with a lower fee. Notably, the program did not collapse as the Commission spokesmen feared it would. This effort on the part of the House Committee to introduce a greater degree of economy into the AEC community operations can definitely be called a success. While actual dollar

${ }^{22}$ U.S. Atomic Energy Commission, "General Manager's Bulletin," GM-BUD-3, Serial No. 149, and AEC Manual, Vol. 1000, pt. 300, chaps. 1304 and 1305.

${ }^{23} \mathrm{~A}$ minor rider relating to construction appeared in the fiscal year 1952 appropriations bill and provided that funds contained in the AEC appropriation should not be used for any new construction project until after the Commission had "notified all architects and engineers involved that the plans for such projects should be purely utilitarian and without unnecessary refinements." Pub. L. No. 137, 82d Cong., 1st Sess., 65 Stat. at L. 269. Despite a letter from Chairman Dean, which Senator Maybank read into the Congressional Record [82d Cong., 1st Sess., Vol. 97, p. 6713 (June 19, 1951)], predicting dire results if this provision remained in the bill, it appears that the Commission was able to satisfy the requirements without undue inconvenience.

${ }^{24}$ See Report to Accompany H. R. 6829, Supplemental Independent Offices Appropriations Bill, 1949, 80th Cong., 2d Sess., H. R. Rep. No. 2245, p. 3 (June 8, 1948), and Report to Accompany H. R. 4177, Independent Offices Appropriations Bill, 1950, 81st Cong., 1st Sess., H. R. Rep. No. 425, p. 3 (April 11, 1949). 
savings were small, especially in view of the fact that the contractor whose fee had been cut sued the government successfully for breach of contract, it was a clear triumph in principle for the House Committee over the vehement opposition from the Commission and the Joint Committee on Atomic Energy.

\section{The Degree of Control}

The Appropriations Committees have made hardly any impact on the scope and scale of the atomic energy program. They have made more of an impact in controlling administrative operations by specific limitations and procedural requirements written into appropriation acts. Thus the over-all impact can be summed up as follows: to a very great extent in the area of program development and to a lesser extent in the area of administration the AEC appears to have been freed from appropriations control.

Other studies of the impact of appropriations control on particular programs and administrative agencies have not come to light. Hence, the results obtained here for the AEC can not now be compared with those obtained from studies of other executive agencies. A nonsystematic search of the history of other appropriations statutes reveals a generally greater use of reductions in budget estimates and of language limitations by the Appropriations Committees. Accordingly, if one were to draw a continuum reaching from the agencies least subject to appropriations control to the agencies most subject to appropriations control, the AEC should be placed among those agencies least controlled.

\section{A Hypothesis of Causes}

What are the characteristics of the atomic energy operation which appear likely to account for this low degree of appropriations control? The AEC was always conditioned by the need for speed in its program. Thus the natural tendency of administrators to stress program adequacy (the accomplishment of results regardless of costs) was greatly fortified, and the $\mathrm{AEC}$ consciousness of urgency made them extremely sensitive to the smallest appropriations restriction and extremely resistant to the suasion of the committees in behalf of economy and efficiency.

Organizationally, the AEC was able to resist appropriations control by its use of the contractor system. By this device the AEC arranged with business firms to perform its manufacturing, research, and developmental duties. The general doctrine of the Commission was opposed to the employment of a large number of government supervisors of the AEC's vast contractual operation. Therefore, inefficiency, if it was a problem in the AEC, mostly concerned contractor operations rather than merely the direct operations of the AEC itself. And in contractor operations the Appropria- 
tions Committees were not readily able to attack inefficiency. They could not impose limitations of appropriation acts directly on the contractors' budget authorizations. Moreover, they were prone to follow the American theory that private business is ipso facto efficient and to assume that this efficiency would carry over into the contractual operation performed for the government. Unavoidably then, the contractor system frustrated the Appropriations Committees, because the government officials were neither directly in charge of administrative operations nor sufficiently numerous to keep careful check on the business contractors.

The low degree of appropriations control over the AEC has one overriding cause inhering in the nature of the AEC's program. A mission vital to national defense and security endows an executive agency with considerable protection from legislative encroachment. The AEC's mission is paramount to national defense, sensitive to the barometer of international tensions, and infused with a sense of urgency exceeding that of any other single operation of the national government.

Although the importance of the AEC program for national defense acts as a general curb on appropriations control, it must be emphasized that there are certain qualifications of this broad generalization. First, there is the matter of time. As familiarization with the agency's program is gained, Appropriations Committees become more adept at exercising control without endangering the whole program. For example, contrary to its early hesitant approach, the House Appropriations Committee in July, 1952, boldly insisted on a procedure by which the AEC had to present concrete plans and procedures before starting any new construction activity. Second, there is the matter of the directness of the relationship of different aspects of the program to national defense. For example, restrictions over the research features of the program have been more stringent than those over raw materials procurement; similarly, as the AEC expands its peaceful atomic power activities they will be susceptible to greater control than has been the atomic weapons program.

To repeat, then, the fear of the Appropriations Committees to take the responsibility for injuring so vital a defense program is the major reason why these Committees do not exercise strong appropriations control over the AEC. It is likely that appropriations control is weak also over other federal defense programs, but a great amount of research will be necessary to prove it. 